Pesq. Vet. Bras. 35(2):119-124, fevereiro 2015 DOI: 10.1590/S0100-736X2015000200004

\title{
Cytoskeletal proteins in the follicular wall of normal and cystic ovaries of sows ${ }^{1}$
}

\author{
Fabiano J.F. de Sant'Ana²* Janildo L. Reis Junior², Rosélia L.S. Araújo², \\ Eduardo J.Gimeno ${ }^{3}$ and Hugo H. Ortega ${ }^{4}$
}

\begin{abstract}
Sant'Ana F.J.F., Reis Jr J.L., Araújo R.L.S., Gimeno E.J. \& Ortega H.H. 2015. Cytoskeletal proteins in the follicular wall of normal and cystic ovaries of sows. Pesquisa Veterinária Brasileira 35(2):119-124. Laboratório de Patologia Veterinária, Universidade de Brasília, Campus Universitário Darcy Ribeiro, Brasília, DF 70910-900, Brazil. E-mail: santanafjf@yahoo.com

The expression of cytoskeletal proteins was evaluated immunohistochemically in 36 normal ovaries sampled from 18 sows and 44 cystic ovaries sampled from of 22 sows, was evaluated. All sows had history of reproductive problems, such as infertility or subfertility. The immunohistochemically stained area (IHCSA) was quantified through image analysis to evaluate the expression of these proteins in the follicular wall of secondary, tertiary, and cystic follicles. Cytokeratins (CK) immunoreactivity was strong in the granulosa cell layer (GC) and mild in the theca interna (TI) and externa (TE) of the normal follicles. There was severe reduction of the reaction to $\mathrm{CK}$ in the GC in the cystic follicles, mainly in the luteinized cysts. The immunoreactivity for vimentin was higher in the GC from normal and cystic follicles in contrast with the other follicular structures. In the luteinized cysts, the IHCSA for vimentin was significantly higher in TI and in both observed cysts, the labeling was more accentuated in TE. Immunohistochemical detection of desmin and $\alpha$-SMA was restricted to the TE, without differences between the normal and cystic follicles. The results of the current study show that the development of ovarian cysts in sows is associated to changes in the expression of the cytoskeletal proteins $\mathrm{CK}$ and vimentin.
\end{abstract}

INDEX TERMS: Ovarian cysts, ovary, cytoskeletal proteins, swine.

RESUMO.- [Proteínas do citoesqueleto na parede folicular de ovários normais e císticos de porcas matrizes.] A expressão de proteínas do citoesqueleto foi avaliada por imuno-histoquímica em ovários normais e císticos de porcas matrizes. Amostras de 36 ovários normais (18 porcas) e de 44 císticos (22 porcas) foram avaliadas. Todas as matrizes apresentaram histórico de problemas reprodutivos, como infertilidade ou subfertilidade. As áreas coradas por imuno-histoquímica (IHCSA) foram quantificadas por avaliação de imagens avaliando a expressão dessas proteínas na parede folicular de folículos secundários, terciários e císticos. A imuno-reatividade para citoqueratina (CK) foi forte

\footnotetext{
${ }^{1}$ Received on December 13, 2014.

Accepted for publication on February 12, 2015.

${ }^{2}$ Laboratório de Patologia Veterinária (LPV), Universidade de Brasília (UnB), Brasília, DF 70910-900, Brazil. *Corresponding author: santanafjf@yahoo.com

${ }^{3}$ Faculdad de Ciencias Veterinárias, National University of La Plata, Calle 60 y 118, 1900 La Plata, Argentina.

${ }^{4}$ Faculdad de Ciencias Veterinarias, Universidad Nacional del Litoral, Calle Kreder 2805, S3080HOF, Esperanza, Argentina.
}

na camada de células da granulosa (GC) e discreta nas tecas interna (TI) e externa (TE) dos folículos normais. Houve redução acentuada da reação de CK na CG dos folículos císticos, principalmente nos cistos luteinizados. A reação para vimentina foi mais intensa na CG dos folículos normais e císticos em comparação com outras estruturas foliculares. Nos cistos luteinizados, a IHCSA para vimentina foi significativamente maior na TI e, em ambos os cistos observados, a marcação foi mais acentuada na TE. A marcação de desmina e actina alfa de músculo liso foi restrita a TE, sem diferenças entre os folículos normais e císticos. Os resultados do presente estudo mostram que o desenvolvimento de cistos ovarianos em porcas matrizes está associado a alterações na expressão das proteínas do citoesqueleto CK e vimentina.

TERMOS DE INDEXAÇÃO: Cistos ovarianos, ovário, proteínas do citoesqueleto, porca matriz.

\section{INTRODUCTION}

Reproductive failure in sows is a common and important problem in pig herds around the world. Anestrus, irregu- 
lar or prolonged estrus cycle, failure to return to heat, repeat breeding, and small litter size are some clinical signs associated to lesions in the reproductive system of sows. Ovarian cyst or cystic follicular disease (CFD) is the main reproductive disorder of sows and causes infertility and significant economic losses (Einarsson \& Gustafsson 1970, Dalin et al. 1997, Heinonen et al. 1998, Schlafer \& Miller 2007). In a study conducted in Finland, approximately $50 \%$ of 1708 reproductive organs of sows and gilts presented ovarian alterations and $6.2 \%$ of these lesions consisted of variable degrees of CFD (Heinonen et al. 1998).

Morphologically the ovarian cysts in sows can be small (1-2cm in diameter) and multiple. Usually, the small cysts do not present luteinization in their walls and are named cysts of the estrogenic type. The cysts can be also multiple and large. Generally, these late cysts have luteinization in their walls and are called cysts of the progesteronic type (Nascimento \& Santos 2011). Multiple luteinized cysts, some with $5 \mathrm{~cm}$ in diameter, characterize the CFD in sows (Schlafer \& Miller 2007).

The pathogenesis of the cystic ovarian disease (COD) in cows has been objective of studies and researches for many years, but is still poorly understood. Some authors believe that the etiology is multifactorial (Peter 2004). In cows, the development of the cyst has been associated to many ambient, clinic, and hereditary factors (Garverick 1997, Monniaux et al. 2008). Possibly, the stress contributes with the formation of the CFD in sows (Scholten \& Liptrap 1978). Some researchers cite endocrine disorders affecting the hypothalamo-hypophyseal axis related to development of the ovarian cysts in sows (Scholten \& Liptrap 1978) and cows (Garverick 1997, Silvia et al. 2002, Vanholder et al. 2006). Recent investigation revealed that apoptosis and cell proliferation were altered in swine cystic follicles (Sun et al. 2012). Previous studies have demonstrated that changes and destabilization of the cytoskeletal proteins (microtubules, microfilaments and intermediate filaments) of the ovary decrease hardly the production of steroid hormones and can contribute with the cystogenesis (Chen et al. 1994). Although the expression of cytoskeletal proteins has been studied in normal ovarian structures of many species including the sheep (Marettova \& Maretta 2002), cow (Van der Huck et al. 1995) and rat (Selstam et al. 1993), there are no investigations about the expression of these proteins in normal and affected swine ovary. Recently, it was suggested that cytoskeletal proteins conducting the functional and structural changes during the cystogenesis participated in the pathogenesis of the COD in rats (Salvetti et al. 2004) and in cows (Ortega et al. 2007b). These proteins contribute to the structural integrity of cells and participate in cell-to-cell binding, differentiation events, and proliferation (Luna \& Hitt 1992). The cytoskeleton is composed by three distinct polymers known as microfilaments, microtubules, and intermediate filaments. Microfilaments and microtubules are homogeneous structures, whereas intermediate filaments (IF) include heterogeneous fibers, such as cytokeratins, vimentin and desmin. These IFs are found in epithelial, mesenchymal and muscle cells (skeletal, cardiac, and smooth), respectively. In addition, it is thought that, in some cases, vimentin behaves like a maturation marker and occur in cultured cells of myogenic and neurogenic origin (Salvetti et al. 2004). Smooth muscle actin ( $\alpha$-SMA) is a cytoskeleton protein classified into microfilaments group that is present in smooth muscle cells (Alberts et al. 1994).

This work aims to characterize by immunohistochemistry analysis the expression of cytoskeletal proteins in the follicular wall of cystic and normal ovary of sows.

\section{MATERIALS AND METHODS}

Animals and post-mortem examination. The ovaries of 40 sexually mature sows, with $(n=22)$ and without $(n=18)$ cysts, were used in this study. The animals were obtained from a slaughterhouse of Goiás, Brazil. Sows were submitted to the slaughterhouse due to reproductive problems, such as infertility or subfertility.

After evisceration, sections of each ovary were collected for histological and immunohistochemical analysis. The samples were fixed in $10 \%$ neutral buffered formalin for $24 \mathrm{~h}$, embedded in paraffin and cut into 3-4 $\mu \mathrm{m}$ thick sections. The sections were stained with hematoxylin-eosin (HE).

Classification of follicles. Follicles were classified microscopically in primordial, primary, secondary and tertiary according to the criteria listed in Nomina Histologica (1994). Grossly, the cysts were classified in single and multiple, and histologically, in follicular and luteinized (Schlafer \& Miller 2007). Eighteen follicles of the categories normal (secondary and tertiary) and affected (luteinized), and 12 follicular cysts were analyzed.

Immunohistochemistry. Details and concentration of antibodies used are summarized in Table 1. A streptavidin-biotin method was used as previously described (Salvetti et al. 2004). In brief, sections were deparaffinized, hydrated, and microwave pre-treatment (antigen retrieval) was performed by incubating the sections in $0.01 \mathrm{M}$ citrate buffer $(\mathrm{pH} 6)$. Endogenous peroxidase activity was inhibited with $1 \% \mathrm{H}_{2} \mathrm{O}_{2}$ and non-specific binding was blocked with $10 \%$ normal goat serum. All sections were incubated with primary antibodies for $18 \mathrm{~h}$ at $4^{\circ} \mathrm{C}$. The fragments were washed and then incubated for $30 \mathrm{~min}$ at room temperature with pre-absorbed biotinylated secondary antibodies, selected for each of the types of primary antibody used (monoclonal or polyclonal). Streptavidin-peroxidase method (BioGenex, San Ramon, CA, USA) and 3,3'-diaminobenzidine (Liquid DAB-Plus Substrate Kit; Zymed, San Francisco, CA, USA) were used as the detection system. Later, the slides were washed in distilled water and counterstained with Mayer's hematoxylin, dehydrated and mounted. Sections of skin and heart were used as positive controls. For negative controls, instead of the primary antibodies, a phosphate-buffered saline (PBS) solution was used.

Image analysis. Image analysis of the immunoreaction in tissue sections was performed by color segmentation analysis with the Image Pro-Plus 3.0.1 system (Media Cybernetics, Silver Spring, MA, USA) (Salvetti et al. 2004, Ortega et al. 2007b). Briefly, images were digitized with a CCD-colour video camera (Leica ICC50 HD, Heerbrugg, Switzerland) mounted on a conventional light microscope (Leica DM500, Heerbrugg, Switzerland), with an

Table 1. Panel of antibodies used in the current study

\begin{tabular}{lccc}
\hline \multicolumn{1}{c}{ Antibody specificity } & Source & Clone & Dilution \\
\hline Alpha smooth muscle actin ( $\alpha$-SMA) & Novocastra & $\alpha$ sm-1 & $1: 50$ \\
Desmin & Zymed & H2 & Prediluted \\
Cytokeratin (Pan AE1/AE3) & Dako & H94 & $1: 500$ \\
Vimentin & Zymed & H9 & $1: 100$
\end{tabular}


objective magnification of X40. The details of image analysis as a valid method for quantifying expression, and the methodological details, were described previously (Ortega et al. 2004). The immunoreactivity in the wall of the blood vessels was used to provide internal controls, and positive controls were used as interassay controls to maximize the level of accuracy of the method (Ranefall et al. 1998). Microscopical fields covering the entire follicular wall area were digitized and stored in a 24-bit true color tagged image file format (TIFF).

To obtain quantitative data regarding immunohistochemical reactivity in the follicular wall, at least three sections for each specimen and antibody were evaluated and 45 representative fields were analyzed. By means of AutoPro macro language, an automated sequence operation was created to measure the immunohistochemically stained (labelled) area (IHCSA). IHCSA was calculated as a percentage of total area evaluated by color segmentation analysis, which extracts objects by locating all objects of a specific color (brown). The brown label was selected and a mask was then applied to make the separation of colors permanent. The images were then transformed to a bi-level scale TIFF. The IHCSA (black area) was calculated from at least 50 images of each area (granulosa, theca externa, and theca interna) in each slide (Salvetti et al. 2004 , Ortega et al. 2007a). The major strength of the well-validated imaging approach used in this study is the visualization of in situ localization of proteins within cells of interest. Quantification of biological markers using this approach has been successfully applied to quantify immunoreactivity in different tissues (Lejeune et al.2008, Ortega et al. 2009a). This type of densitometrical methodology has been previously validated by biochemical methods of protein induction and quantification (Peretti-Renucci et al. 1991).

The data were expressed as the mean \pm standard error of mean (SEM). The IHCSA of each antibody in different areas and structures and the morphometric data were analyzed by means of the ANOVA test and the Duncan post-test.

\section{RESULTS}

\section{Morphology}

Thirty-six ovaries (18 animals) do not showed morphologic alterations, exhibiting follicles in different stages, including primordial, primary, secondary and tertiary follicles, corpus luteum and corpora albicans. Macroscopic and microscopic examination showed that 44 ovaries ( 22 sows) presented cysts $(2.2-4.0 \mathrm{~cm}$ in diameter $)$. In the majority of these cases (42/44), the cysts were multiple, bilateral and occupied almost the entire ovarian parenchyma. The multiple follicular cysts were characterized for a large antral cavity and atrophy and disorganization of the granulosa cell (GC) layers and of theca interna (TI) and externa (TE). The multiple luteinized cysts were similar to follicular cysts, but there was no GC or this layer was severely atrophied and hyalinized. Furthermore, there was moderate to severe luteinization of the TI and TE. Only two ovaries presented single luteinized cyst and these cases was not considered for evaluation.

\section{Immunohistochemistry}

The immunohistochemical expressions of the used antibodies are shown in Table 2. The immunoreactions were negative in all negative controls and positive in the positive controls.

In the follicular wall, the labeling to $\alpha$-SMA was re- stricted to TE and negative in the TI and CG (Fig.1). There was no significant differences among the IHCSAs of the normal and cystic follicular structures $(\mathrm{P}>0.05)$. Smooth muscle cells including those present in the cortical and medullar blood vessel walls functioned as internal control to $\alpha$-SMA.

Similar to immunohistochemical reaction observed with $\alpha$-SMA, the reactivity for desmin was limited to TE (Fig.2), without differences between the normal and cystic follicles $(\mathrm{P}>0.05)$. Some interstitial mesenchymal cells of the medullary and cortical stroma and the blood vessel wall showed moderate to strong positive reaction for desmin.

In all normal and cystic follicles, there was positive reaction to CK. CK immunoreactivity was strong in the GC and mild in the TI and TE of the secondary and tertiary follicles (Fig.3A and $3 \mathrm{~B})(\mathrm{P}<0,05)$. There was severe reduction of

Table 2. Mean and standard error of the immunohistochemically stained area (IHCSA) by cytoskeletal proteins in follicular structures of normal and cystic ovaries of sows

\begin{tabular}{ccccc}
\hline Antibody & $\begin{array}{c}\text { Seconda- } \\
\text { ryfollicle }\end{array}$ & Terciaryfollicle & Follicularcyst Luteinizedcyst \\
\hline$\alpha$-SMA & & & & \\
GC & - & - & - & - \\
TI & - & - & - & - \\
TE & $11.32+2.14 \mathrm{a}$ & $10.85+1.89 \mathrm{a}$ & $10.62+3.31^{\mathrm{a}}$ & $12.18+2.52 \mathrm{a}$ \\
Desmin & & & & - \\
GC & - & - & - & - \\
TI & - & - & - & $5.62+1.2 \mathrm{a}$ \\
TE & $8.26+2.59 \mathrm{a}$ & $7.11+2.1 \mathrm{a}$ & $6.75+1.83^{\mathrm{a}}$ & \\
CK & & & & \\
GC & $10.89+2.55 \mathrm{aA}$ & $8.39+0.47 \mathrm{aA}$ & $2.74+1.35 \mathrm{bA}$ & $0.35+0.25 \mathrm{bA}$ \\
TI & $1.64+0.83 \mathrm{aB}$ & $0.78+0.39 \mathrm{aB}$ & $1.57+1.16 \mathrm{aA}$ & $3.38+1.82 \mathrm{bB}$ \\
TE & $0.69+0.39 \mathrm{aB}$ & - & $0.87+0.72 \mathrm{aA}$ & $0.98+0.5 \mathrm{aA}$ \\
Vimentin & & & & \\
GC & $9.41+2.35 \mathrm{aA}$ & $9.77+2.71 \mathrm{aA}$ & $10.98+1.01 \mathrm{aA}$ & $8.64+2.44 \mathrm{aA}$ \\
TI & $3.9+1.76 \mathrm{aB}$ & $7.88+2.05 \mathrm{aA}$ & $4.66+1.97 \mathrm{aB}$ & $16.86+5.01 \mathrm{bB}$ \\
TE & $2.33+0.9 \mathrm{aB}$ & $4.63+0.21 \mathrm{bB}$ & $9.91+1.92 \mathrm{cA}$ & $12.03+2.6 \mathrm{cA}$
\end{tabular}

$\alpha$-SMA $=\alpha$-Smooth Muscle Actin, $\mathrm{CK}=$ cytokeratin, GC = granulosa layer, $\mathrm{TI}$ = theca interna, $\mathrm{TE}=$ theca externa. In horizontal rows, means followed of distinct lowercase letters differ significantly $(\mathrm{P}<0,05)$. In columns, means followed of distinct capital letters differ significantly $(\mathrm{P}<0,05)$.

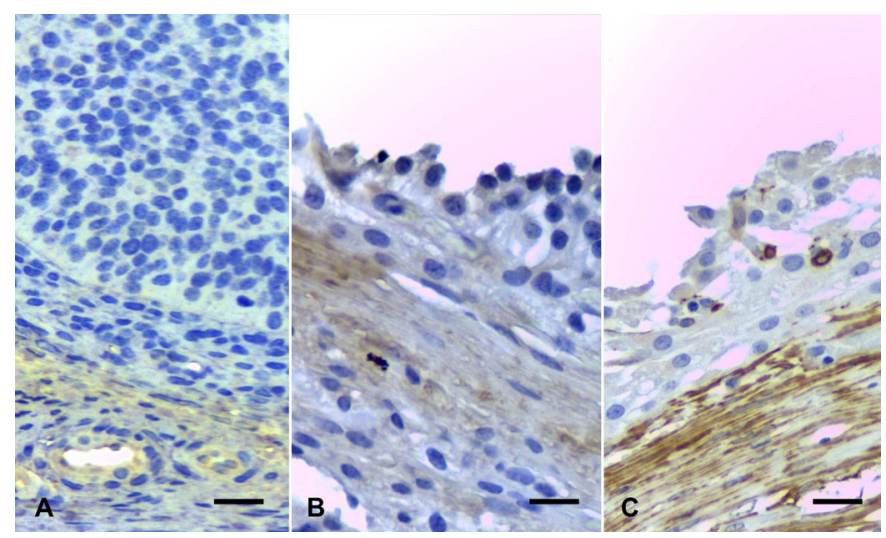

Fig.1. (A) Immunohistochemical localization of alpha smooth muscle actin in secondary follicles, (B) follicular cyst, and (C) luteinized cyst is restricted to the theca externa. Bars $=24 \mu \mathrm{m}$. 


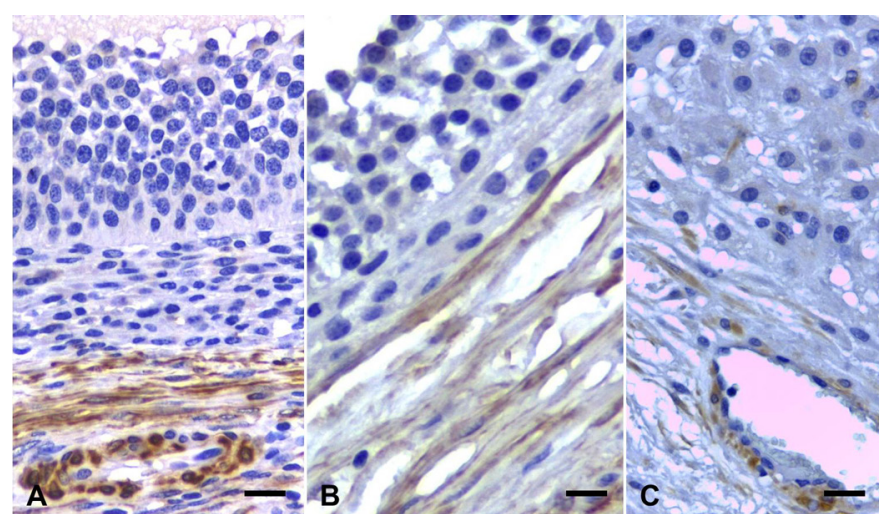

Fig.2. (A) Immunohistochemical reactivity to desmin in secondary follicles, (B) follicular cyst and (C) luteinized cyst is restricted to theca externa. Bars $=24 \mu \mathrm{m}$

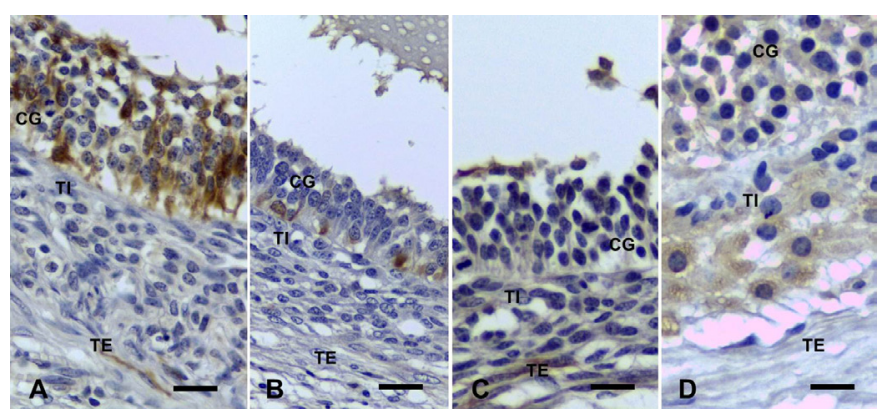

Fig.3. Immunohistochemical reaction to cytokeratin (CK) (A) in secondary and (B) tertiary follicles, and (C) in follicular and (D) luteinized cysts. The immunoreactivity is strong in the granulosa cell layer (CG) and mild in the thecasinterna (TI) and externa(TE) of the secondary and tertiary follicles. Note severe reduction of the marcation to $\mathrm{CK}$ in the $\mathrm{GC}$ of the cystic and luteinized follicles. Bars $=24 \mu \mathrm{m}$.

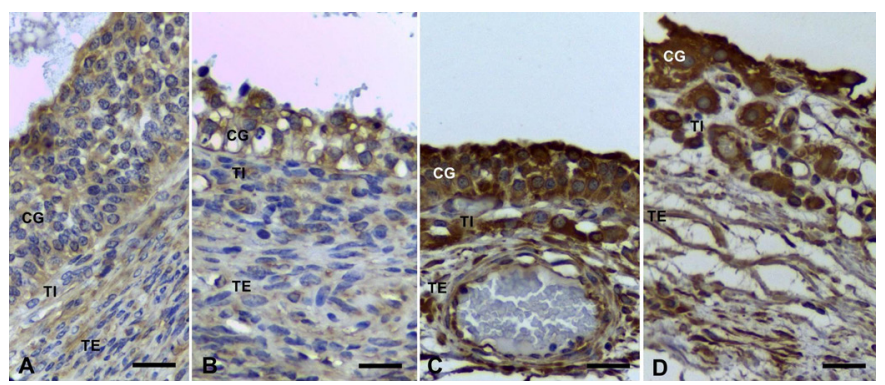

Fig.4. Immunohistochemical demonstration of vimentin (A) in secondary and (B) tertiary follicles, and (C) follicular and (D) luteinized cysts. The reaction is higher in the granulosa cell layer (GC) of normal and cystic follicles in contrast with the other follicular layers. In the luteinized cysts, the IHCSA for vimentin was significantly higher in theca interna(TI) and in both observed cysts, the labeling was more accentuated in theca externa (TE). Bars $=30 \mu \mathrm{m}$.

the binding to $\mathrm{CK}$ in the $\mathrm{GC}$ of the cystic follicles, mainly in the luteinized cysts (Fig. $3 \mathrm{C}$ and $3 \mathrm{D})(\mathrm{P}<0,05)$. A reaction in the TI of the luteinized cysts was significantly higher in contrast to the other follicular structures $(\mathrm{P}<0,05)$. In addition, strong reactivity in the cells of the GC of the primordial follicles and follicular fluid was noted. The epithelium of ovarian surface presented homogeneous and strong re- action to $\mathrm{CK}$, functioning as positive internal control.

In all normal and cystic follicles, there was positive labeling to vimentin. The immunoreactivity for this antibody was higher in the GC of normal and cystic follicles in contrast with the other follicular structures (Fig.4) $(\mathrm{P}<0,05)$. $\mathrm{GC}$ of the primordial follicles and some mesenchymal cells presented moderate positive reaction. In the luteinized cysts, the IHCSA for vimentin was significantly higher in TI $(\mathrm{P}<0,05)$ and in both observed cysts, the labeling was more accentuated in $\mathrm{TE}(\mathrm{P}<0,05)$.

\section{DISCUSSION}

Although cystic ovaries is considered a common and important economically reproductive disease of domestic animals, the mechanisms that leading to development of these cysts have been object of speculation and research for many years, but are not fully understood (Wiltbank et al. 2003). Many studies have demonstrated changes and pathogenetic mechanisms evolved in follicular cyst in cattle (Garverick 1997, Isobe \& Yoshimura 2007, Ortega et al. 2007b, Monniaux et al. 2008, Ortega et al. 2008, Rey et al. 2010), rat (Anderson \& Lee 1997, Ortega et al. 2007a, Salvetti et al. 2009) and women (Abbot et al. 2002, Ortega et al. 2009b), but few investigations have been conducted in the genesis of this condition in sows. The current study shows that the formation of ovarian cysts in sows is associated to alterations in the expression of some cytoskeletal proteins. These molecules act in the formation of cell contacts and in the determination of the cell morphology (Schliwa \& Van Blerkom 1981, Luna \& Hitt 1992). Changes in the intermediate filaments have also been observed in ovine normal ovaries, affecting the organization of the cytoskeleton of corpus luteum and atresic follicles (Marettova \& Maretta 2002). In addition, studies have demonstrated that pharmacologic agents which destabilize the cytoskeletal proteins can affect considerably the production of steroid hormones (Chen et al. 1994), determining important changes in the steroidogenesis and consequently in cystogenesis (Isobe et al. 2003).

In the current investigation, no significant alterations in the areas of immunoreaction for desmin and $\alpha$-SMA between the normal and cystic follicles were found, suggesting that these expressions are restrict the stable structures that either do not participate or are not changed during the cystogenesis. Furthermore, the reaction for these antibodies was limited to TE. Very similar dates were observed in previous studies conducted in cows (van der Hurk et al. 1995, Ortega et al. 2007b) and rats (Salvetti et al. 2004). Desmin and $\alpha$-SMA are important antibodies used to labeling of muscle cells in general (skeletal, cardiac, and smooth) and smooth muscle cells, respectively, in normal and pathological situations. Alterations in the ovarian immunoreaction of these antibodies can indicate stromal disturbs related to formation of lesions, such as cysts.

The CK reactivity was more marked in GC and discrete in the TI and TE of the healthy follicles, as observed in normal follicles of cows (Ortega et al. 2007b). However, in the current study, there was significant reduction of the IHCSAs for GC in the two types of analyzed cysts. On the other hand, 
the expression of CK in the GC was increased in rats and cows with ovarian follicular cysts (Salvetti et al. 2004, Ortega et al. 2007b). These results demonstrate the importance of the animal species in relation the changes related to reactivity of cytoskeletal proteins in ovarian structures. Furthermore, in the ovaries of the current investigation, there was atrophy of the epithelium of the GC in many cysts. This fact could contribute with the reduced expression of CK. These IF is found regularly in epithelial cells and present wide diversity of subunits (Alberts et al. 1994).

The immunoreactivity for vimentin was stronger in GC in comparison to TI and TE in the normal follicles. In experimental and natural studies of cystic ovaries performed in rats (Salvetti et al. 2004) and cows (Ortega et al. 2007b), there was similar expression for this intermediate filament in the TI and GC. The pathologic date of the present study are partially similar to noted previously in bovine ovarian cysts, that also observed higher IHCSA for vimentin in the TE of follicular cysts (Ortega et al. 2007b). In addition, the strong reaction of this protein in the TI of the luteinized cysts of sows was attributed to numerous positive luteinized cells present in this affected layer. Vimentin occur in many cells of mesodermic origin, such as fibroblasts, endothelial cells and other mesenchymal cells, but is also expressed transitory in many cells during the development (Alberts et al. 1994).

\section{CONCLUSION}

The results of the current study suggest that changes in the reactivity to vimentin and cytokeratin observed in the wall of follicular and luteinized cysts in sows, probably reflect structural and functional alterations during the cystogenesis, as noted in cows (Ortega et al. 2007b) and rats (Salvetti et al. 2004).

Acknowledgements.- This study was funded by Conselho Nacional de Desenvolvimento Científico e Tecnológico (CNPq), Brazil (Proc. 471907/2011-1). The authors would like to thank for the Frigorífico BRF S.A. (Rio Verde, Goiás, Brazil) for provide the ovary samples used in the study. E.J.G. and H.H.O. are Research Career Members of the Consejo Nacional de Investigaciones Científicas y Técnicas (CONICET), Argentina. R.L.S.A. is a Scholar of CNPq, Brazil.

\section{REFERENCES}

Abbott D.H., Dumesic D.A. \& Franks S. 2002. Developmental origin of polycystic ovary syndrome: a hypothesis. J. Endocrinol. 17:41-45.

Alberts B., Bray D., Lewis J., Raff M., Roberts K. \& Watson J.D. 1994. Molecular Biology of the Cell. Garland, New York, p.787-861.

Anderson E. \& Lee G.Y. 1997. The polycystic ovarian (PCOD) condition: apoptosis and epithelization of the ovarian antral follicles are aspects of cystogenesis in the dehydroepiandrosterone (DHEA)-treated rat model. Tissue Cell 29:171-189.

Chen T.T., Massey P.J. \& Caudle M.R. 1994. The inhibitory action of taxol on granulosa cell steroidogenesis is reversible. Endocrinology 134:21782183.

Dalin A.M., Gidlund K. \& Eliasson-Selling L. 1997. Post-mortem examination of genital organs from sows with reproductive disturbances in a sow-pool. Acta Vet. Scand. 38:253-262.

Einarsson S. \& Gustafsson B. 1970. Developmental abnormalities of female sexual organs in swine; a post-mortem examination of the genital tract in 1000 gilts. Acta Vet. Scand.11:427-442.
Garverick H.A. 1997. Ovarian follicular cysts in dairy cows. J. Dairy Sci. 80:995-1004.

Heinonen M., Leppävuori A. \& Pyörälä S. 1998. Evaluation of reproductive failure of female pigs based on slaughterhouse material and herd record survey. Anim.Reprod. Sci. 52:235-244.

Isobe N., Nakao T. \& Yoshimura Y. 2003. Immunohistochemical localization of $3-\beta$-hydroxysteroid dehydrogenase in the granulosa and theca interna layers of bovine cystic follicles. J. Reprod. Dev. 49:227-233.

Isobe N. \& Yoshimura Y. 2007. Deficient proliferation and apoptosis in the granulosa and theca interna cells of the bovine cystic follicle. J. Reprod. Dev. 53:1119-1124.

Lejeune M., Jaen J., Pons L., Lopez C., Salvado M.T., Bosch R., García M., Escrivà P., Baucells J., Cugat X. \& Alvaro T. 2008. Quantification of diverse subcellular immunohistochemical markers with clinicobiological relevancies: validation of a new computer-assisted image analysis procedure. J. Anat. 212:868-878.

Luna E.J. \& Hitt A.L. 1992. Cytoskeleton-Plasma membrane interactions. Science 258:955-963.

Marettova E. \& Maretta M. 2002. Demonstration of intermediate filaments in sheep ovary. Acta Histochem. 104:431-434.

Monniaux D., Clemente N., Touzé J.L., Belville C., Rico C., Bontoux M., Picard J.Y. \& Fabre S. 2008. Intrafollicular steroids and anti-mullerian hormone during normal and cystic ovarian follicular development in the cow. Biol. Reprod. 79:387-396.

Nascimento E.F. \& Santos R.L. 2011. Patologia da Reprodução dos Animais Domésticos. 3a ed. Guanabara Kooghan, Rio de Janeiro, p.15-36.

Nomina Histologica 1994. International Committee on Veterinary Histological Nomenclature. 2nd ed. Cornell University, New York, p.38.

Ortega H.H., Lorente J.A., Mira G.A., Baravalle C. \& Salvetti N.R. 2004. Constant light exposure causes dissociation in gonadotrophins secretion and inhibits partially neuroendocrine differentiation of Leydig cells in adult rats. Reprod. Dom. Anim. 39:417-423.

Ortega H.H., Amable P., Salvetti N.R., Dallard B.E., Baravalle C., Barbeito C.G. \& Gimeno E.J. 2007a. Intraovarian localization of growth factors in induced cystic ovaries in rats. Anat. Histol. Embryol. 36:94-102.

Ortega H.H., Salvetti N.R., Müller L.A., Amable P., Lorente J.A., Barbeito C.G. \& Gimeno E.J. 2007b. Characterization of cytoskeletal proteins in follicular structures of cows with cystic ovarian disease.J. Comp. Pathol. 136:222-230.

Ortega H.H., Palomar M.M., Acosta J.C., Salvetti N.R., Dallard B.E., Barbeito C.G. \& Gimeno E.J. 2008. Insulin-like growth factor I in ovarian follicles and follicular fluid from cows with spontaneous and induced cystic ovarian disease. Res. Vet. Sci. 84:419-427.

Ortega H.H., Salvetti N.R. \& Padmanabhan V. 2009a. Developmental programming: prenatal androgen excess disrupts ovarian steroid receptor balance. Reproduction 137:865-877.

Ortega H.H., Salvetti N.R., Rey F., Barbeito C.G. \& Gimeno E.J. 2009b. Experimental models: a contribution to understand the intraovarian component of PCOS pathogenesis, p.1-29. In: Ortega H.H. (Ed.), Ovarian Cysts: symptoms, causes and treatment. R.E. Tredwell, Nova Science Publishers, New York.

Peretti-Renucci R., Feuerstein C., Manier M., Lorimier P., Savasta M., Thibault J., Mons N. \& Geffard M. 1991. Quantitative image analysis with densitometry for immunohistochemistry and autoradiography of receptor binding sites--methodological considerations. J. Neurosci. Res. 28:583-600.

Peter A.T. 2004. An update on cystic ovarian degeneration in cattle. Reprod. Dom. Anim. 39:1-7.

Ranefall P., Wester K., Andersson A.C., Busch C. \& Bengtsson E. 1998. Automatic quantification of immunohistochemically stained cell nuclei based on standard reference cells. Analyt. Cell Pathol. 17:111-123.

Rey F., Rodríguez F.M., Salvetti N.R., Palomar M.M., Barbeito C.G., Alfaro N.S. \& Ortega H.H. 2010. Insulin-like growth factor-II and insulin-like growth factor-binding proteins in bovine cystic ovarian disease. J. Comp. Pathol. 142:193-204. 
Salvetti N.R., Gimeno E.J., Lorente J.A. \& Ortega H.H. 2004. Expression of cytoskeletal proteins in the follicular wall of induced ovarian cysts. Cells Tissues Organs 178:117-125.

Salvetti N.R., Panzani C.G., Gimeno E.J., Neme L.G., Alfaro N.S. \& Ortega H.H. 2009. An imbalance between apoptosis and proliferation contributes to follicular persistence in polycystic ovaries in rats. Reprod. Biol. Endocrinol. 7:68.

Schlafer D.H. \& Miller R.B. 2007. Female genital system, p.429-564. In: Maxie M.G. (Ed.), Jubb, Kennedy and Palmer's Pathology of Domestic Animals. Vol.3. Elsevier Saunders, New York.

Schliwa M. \& Van Blerkom J. 1981. Structural interaction of cytoskeletal components. J. Cell Biol. 90:222-235.

Scholten J.A. \& Liptrap R.M. 1978. A role for the adrenal cortex in the onset of cystic ovarian follicles in the sow. Can. J. Comp. Med. 42:525533.

Selstam G., Nilsson I. \& Mattson M.O. 1993. Changes in the ovarian intermediate filament desminduring the luteal phase of the adult pseudo- pregnant rat. Acta Physiol. Scand. 147:123-129.

Silvia W.J., Hatler T.B., Nugent A.M. \& Fonseca L.F.L. 2002. Ovarian follicular cysts in dairy cows: an abnormality in folliculogenesis. Dom. Anim. Endocrinol. 23:167-177.

Sun Y.L., Zhang J., Ping Z.G., Wang C.Q., Sun Y.F., Chen L., Li X.Y., Li C.J., Zhu X.L., Liu Z., Zhang W. \& Zhou X. 2012. Relationship between apoptosis and proliferation in granulosa and theca cells of cystic follicle of sows. Reprod. Dom. Anim. 47:601-608.

Van der Huck R., Dijkstra G., Vanmil F.N., Hulshof S.C. \& Van den Ingh S.G. 1995. Distribution of the intermediate filament proteins vimentin, keratin, and desmin in the bovine ovary. Mol. Reprod. Dev. 41:459-467.

Vanholder T., Opsomer G. \& De Kruif A. 2006. Aetiology and pathogenesis of cystic ovarian follicles in dairy cattle: a review. Reprod. Nutr. Dev. 46:105-119.

Wiltbank M.C., Gumen A. \& Sartori R. 2003. Physiological classification of an ovulatory conditions in cattle. Theriogenology 57:21-52. 